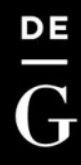

DE GRUYTER

OPEN

DOI 10.2478/pesd-2014-0006

PESD, VOL. 8, no. 1, 2014

\title{
CLIMATIC AND HYDROLOGICAL HAZARDS IN JUNE 26-27, 2010 IN THE UPPER BASIN OF TROTUȘ. CASE STUDY: BETWEEN THE PROPOSED PREPARATION AND THE EFFECTS AT AGĂȘ (COUNTY OF BACĂU)
}

\author{
Viorel Paraschiv ${ }^{1}$, Ovidiu-Miron Machidon ${ }^{2}$ Doina Capsa $^{3}$, Judit Găină ${ }^{4}$
}

Key words: hazards, water, climatic, flood, Trotuş

Abstract. The water catchment area of the Trotus river lies on about 4340 square kilometers of which $66 \%$ are in the mountain area of the Central Group of the Eastern Carpathians (Moldo-Transilvans). In recent years the manifestation of natural hazards aggressiveness multiplied. In 2005 (12-13 July) and 2010 (26-27 June) Trotuş Valley was affected by strong floods that have produced great material damage. Hydro-technical works carried out after the 2005 summer hazard were swept away by the 2010 hazard, when were affected about 3,000 households in the upper course of the Trotus, most of the damage being recorded on the Agăs Creek Valley to the confluence with the Trotuş, the administrative territory of the commune Agăş, where about 2000 household suffered. The late melting snow on the Ciuc and Tarcău Mountains peaks mixed with summer rains determined total isolation of the Cotumba, Sulța, Goioasa and Coşnea hamlets. Provisory bridges realized on the main roads on the side valleys, where are many hamlets, renewed in 2009 summer, were quickly clogged and then swept away by the rough waters of the Trotus and its tributaries. In the upper basin of the Trotus. Over the past 20 years have been recorded up phenomena of paroxysm of the climatic and hydrologic hazards among which the creeks Grohotiş and Sulța flooded the villages Goioasa and Sulţa. On the 12-13 July, 2005 the Creek Agăş flooded a part of the Agăş village, about 2 kilometers, in line, of households. Drăcoiu creek broke the wall of channeled flood reached exceptional values, the maximum flow at Vrânceni hydrometric station being of 2800 cubic meters/s (probability of overflow $0,5 \%$ ) and the flood volume here was the biggest of all the existing measurements.

\footnotetext{
${ }^{1}$ Economic Highschool of Tourism, Iaşi-Romania

2 „Alexandru Ioan Cuza” University Iaşi,

${ }^{3}$ Regional Meteorological Centre of Moldova-Romania

${ }^{4}$ Highschoool Sports, Roman-Neamţ, Romania
} 


\section{Research methodology}

- Analysis of weather characteristics overview for the area;

Correlation between temporal evolution of the use of the land and the construction of logging roads and of the mountain access, based on analysis of forestry cartographic materials (research projects, maps);

- Bibliographical study of the diagnosis drawn up by the institutions concerned about the structural analysis of the emergency situation;

- Identification of potential causes which can determine in the future similar hazards;

- Elementary impact study and the watershed more planning in the Trotus side.

2. Analysis of meteorological phenomena produced in the Trotus river basin (upstream from Comaneşti), 25-26 June 2010

At ground level in 25-26 June, 2010 UTC, the synoptic situation is the one on the synoptic map presented in pictures 1,2 . Romania was under a low pressure area which lies like a belt, from the South to the north-Eastern side of the continent with the main centers of low pressure disposed, one in the Northern side of the Black Sea, the other in the Scandinavian Peninsula.

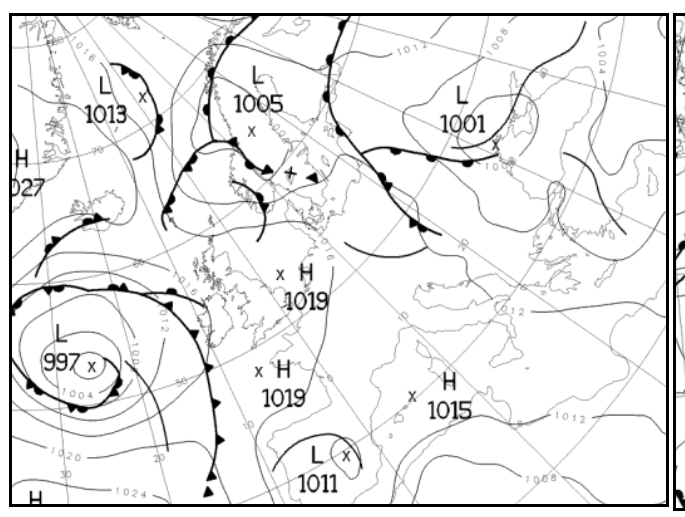

Fig. 1. The frontal ground analysis in June 25, 2010 UTC, h12.00 (source: www.wetter3.de)

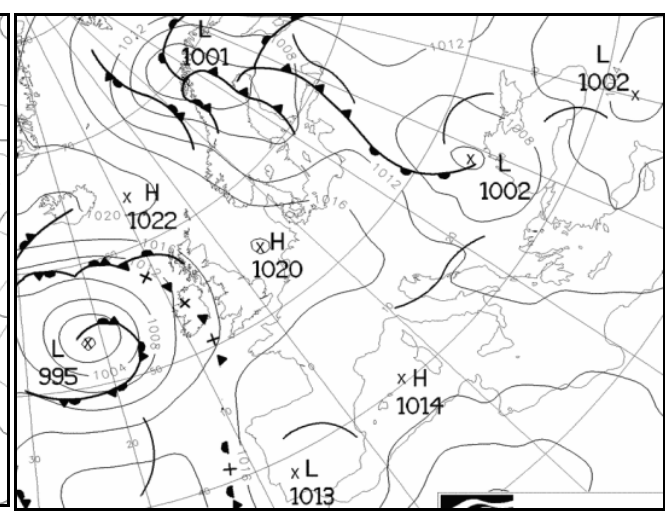

Fig. 2. The frontal ground analysis in June 26, 2010 UTC h6.00 (source: www.wetter3.de)

In the temperature land al the level $850 \mathrm{~h} \mathrm{~Pa}$, our country is under the influence of an air mass of polar maritime origin, the whole territory of Moldavia being situated between $8-10^{\circ}$ (fig 3,4).

CAPE provides a good measure of the degree of instability, representing the amount of potential energy for a high particle at the level of neutral buoyancy. This 
item depends on the initial conditions of the particle and of the thermo-dynamic procedures used to raise the particle, the unit of measurement being $\mathrm{J} / \mathrm{kg}$ (Jouli per kilogram).

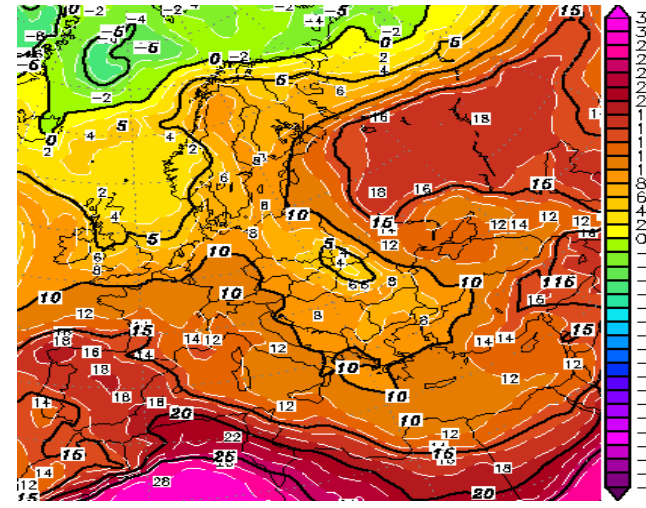

Fig. 3. The surface-level air isobaric temperature of $850 \mathrm{hPa}$ on June 25, 2010, h00.00 UTC

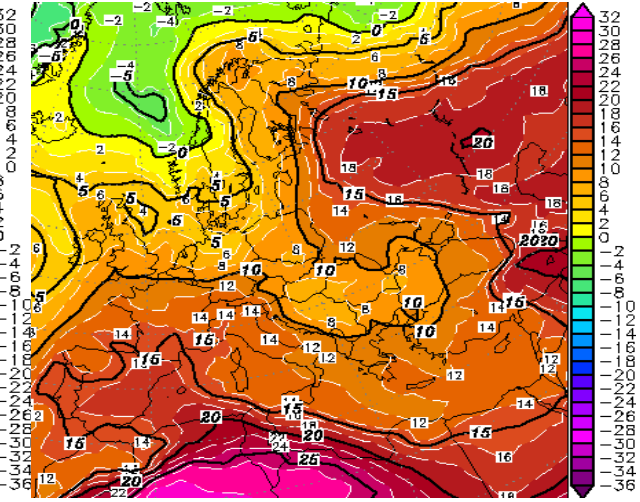

Fig. 4. The surface-level air isobaric temperature of $850 \mathrm{hPa}$ on June 26, 2010, h6.00 UTC

CAPE values for convective storms are about $1000-2000 \mathrm{~J} / \mathrm{kg}$. Sometimes the values could be more then $5000 \mathrm{~J} / \mathrm{kg}$.

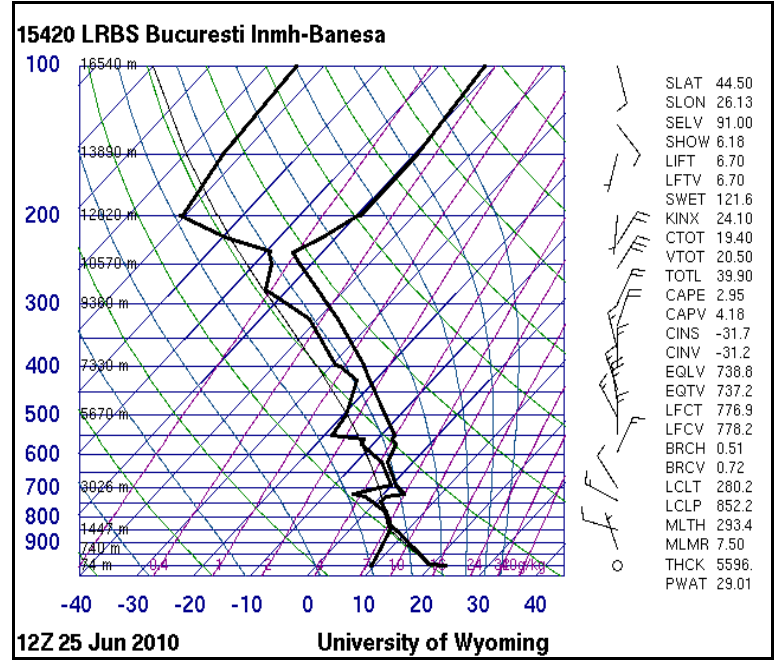

Fig. 5 - Diagram Skew-T from June 25,2010 h 12 UTC (sursa:http://weather.uwyo.edu/upperair/europe.html) 
The diagram (fig.5) where is the vertical profile of the atmosphere and assesses the stability of the atmosphere in Bucharest on June 25, $2010 \mathrm{~h} 12.00$ UTC, indicates: K-INDEX $=24$ (chances to develop clouds $\mathrm{Cb}$ ); CAPE $=295 \mathrm{~J} / \mathrm{kg}$; Total Index $=40$ (probability to appear clouds $\mathrm{Cb}$ ).

Abundant rainfall during the day of June 25, 2010 had front causes (picture 1) accompanied by the instability level during the afternoon (picture 5).

In the first part of the day of June 26, 2010 were met conditions by the occurrence of precipitation due to the hot thermal convection. All these happened as in the pictures from the satellite (fig. 6).

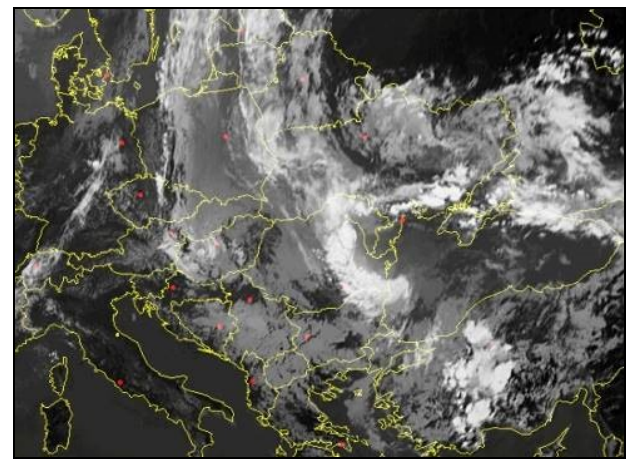

a)

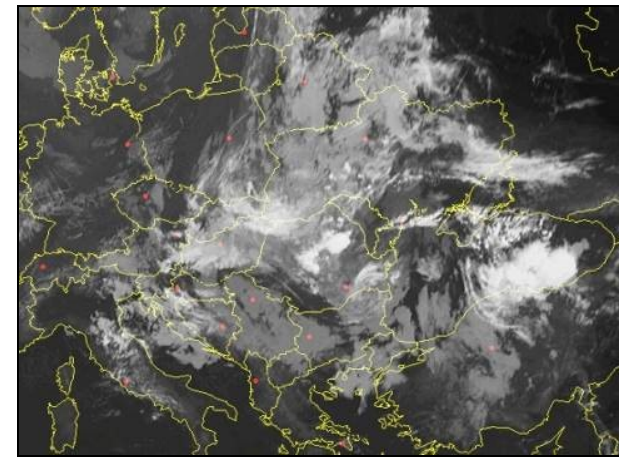

b)

Fig. 6 a,b From satellite, in infrared, on June 25, 2010 h 12.00 UTC (a) and June 26, 2010 h 7.00 UTC (b) (source: http://www.sat24.com/history.aspx)

Tab. 1. The quantities of precipitation $\left(1 / \mathrm{m}^{2}\right)$ confirmed by gauging stations situated in Trotus river basin (upstream from Comanesti)

\begin{tabular}{|c|c|c|}
\hline \multirow{2}{*}{ Gauging stations } & \multicolumn{2}{|c|}{ The quantities of precipitation } \\
\cline { 2 - 3 } & $\begin{array}{c}\text { Between June 25, 2010 h 3.00 } \\
\text { and June 26, 2010 h 3.00 }\end{array}$ & $\begin{array}{c}\text { Between June 26, 2010 h 3.00 } \\
\text { and June 27, 2010 h 3.00 }\end{array}$ \\
\hline Lunca de Sus & 24,5 & 41,1 \\
\hline Ghimeş-Făget & 16,9 & 39,5 \\
\hline Goioasa & 29,6 & 44,1 \\
\hline Ciobănuş & 15,9 & 45,9 \\
\hline
\end{tabular}

The rainy events from June 25-26, 2010 went to the accumulation of large quantities of atmospheric precipitations $\left(>55 \mathrm{l} / \mathrm{m}^{2}\right)$ in Trotus basin (upstream from Comanesti) - tab. 1. This way the level of Trotus river and its affluent have increased significantly being exceeded, local shares and flood attention (tab. 2). 
Tab. 2. The registered shares confirmed by gauging stations situated in Trotus river basin (upstream from Comanesti)

\begin{tabular}{|c|c|c|c|c|c|c|}
\hline \multirow{2}{*}{$\begin{array}{l}\text { Gauging } \\
\text { stations }\end{array}$} & \multirow{2}{*}{$\begin{array}{l}\text { Attention } \\
\text { share (m) }\end{array}$} & \multirow{2}{*}{$\begin{array}{c}\text { Flood } \\
\text { share }(m)\end{array}$} & \multirow[b]{2}{*}{$\begin{array}{c}\text { Danger } \\
\text { share }(m)\end{array}$} & \multicolumn{3}{|c|}{ H (cm) } \\
\hline & & & & $\begin{array}{c}25 \text { June } \\
2010\end{array}$ & $\begin{array}{c}26 \text { June } \\
2010\end{array}$ & $\begin{array}{c}26 \text { June } \\
2010\end{array}$ \\
\hline Lunca de Sus & 100 & 120 & 200 & 65 & 175 & 125 \\
\hline Ghimeş-Făget & 150 & 250 & 300 & 110 & 174 & 168 \\
\hline Goioasa & 150 & 200 & 300 & 88 & 238 & 175 \\
\hline Ciobănuş & 130 & 200 & 250 & 100 & 136 & 109 \\
\hline
\end{tabular}

\section{Overall space requirements}

In the middle and upper basin of Trotus river (upstream from Comanesti) there are $61 \%$ forestry, $34 \%$ agricultural lands (95\% pastures and hayfields and $5 \%$ arable land), the other $5 \%$ being used for other reasons (Dumitriu, 2006), meaning buildings, roads or unused lands. About the forestry it could be seen that near Trotus river it is less, comparing with other basins of the rivers. Here, in the Oriental Carpathians, the forestry lies on important areas (Văcărașu, 1984). After the river springs, going to the middle stream, the surface of the forestry increases. So, from the springs to the confluence with Ciughes the forestry is $30 \%$. In the basins of Cold Valley, Tărhăuş and Ciugheş the forestry is over $40 \%$ and in those of Sulta and Camenca arrives to $60-70 \%$. Over $80 \%$ are in the basins of Ciobanus and Asau streams. Beside this situation arrives another strange situation! Even if there were massive deforestations in the upper basin, at the beginning of the XX century, the damages were less regarding the soil from the middle basin. The maps and the documents prove this situation. The degradation of slopes is due to the fragmentation and of the slow slopes from the upper basin (Văcărașu, 1984). Another reason it could be the incorrect use of the pastures and hayfields comparing with the middle basin.

In the basins of Uz, Dofteana, Slănic, Oituz, Caşin the forestry increases from the springs to the lower basin. So, if in the upper and middle basin the forestry is over $70 \%$, in the lower basin arrives to $30-40 \%$ (Uz, Oituz, Caşin). There is another situation in the upper basin of Uz(with the affluent Apa Lina and Rosu) and Oituz where the pastures and hayfields hold the main share. An increase of the process of erosion could be seen starting from the middle basin of Trotus river due to the pressure of humanity and fragmentation. These are determined by the lithological structure with effect in the dynamics of processes of beds from the major secondary valleys which empties into Trotus river. 


\section{Overall geographical conditions of Agas commune}

The forestry is, statistically, about $60 \%$ from the surface of the commune (tab. 3) but the reality is different.

Tab. 3. Land structure

\begin{tabular}{|c|c|c|c|}
\hline \multirow{3}{*}{ Agricultural land } & Arable & 240 & 0,1 \\
\cline { 2 - 4 } & Pastures & 4629 & 22,2 \\
\cline { 2 - 4 } & Hayfields & 3667 & 17,4 \\
\hline \multirow{3}{*}{$\begin{array}{c}\text { Non-agricultural } \\
\text { land }\end{array}$} & Forests & 12504 & 59,4 \\
\cline { 2 - 4 } & Rivers & 121 & 0,05 \\
\cline { 2 - 4 } & Roads & 254 & 0,1 \\
\cline { 2 - 4 } & Built-up area & 182 & 0,08 \\
\cline { 2 - 4 } & Unused & 50 & 0,02 \\
\hline \multicolumn{2}{|c|}{ Total } & 21040 & $100 \%$ \\
\hline
\end{tabular}

In Agas work about 400 persons the exploitation and processing of wood (2010, source: The Mayor of the commune): 200 on UFET Society and the others at private sawmills. The anthropic pressure on the forestry is overwhelmed and it seems that there is a big difference between the statistics and the reality. The forestry economy and agro-pastoral have $99 \%$ from the administrative surface of the commune. The arable lands are in built-up areas having soils of low fertility, especially podzols.

Analysis of geologic bibliography shows that in Panza of Audia (BrusturoasaAgăş), because of the clay, which is the main, and the irrational use of the land, go to intense erosion in surface, especially on the right slope of the valley, between the confluence of Trotus with Popoi and Ciugheș. Other intense erosion areas were signed on left slope until the confluence with Cuchiniș. A proof of the irrational use of the lands could be seen on the left slope of Trotus valley, between the confluence with Cuchinis and Camenca (Dumitriu, 2008), where appeared local badlands. The transit of silt in Agas is determined by the deep erosion, the torrentiality having the biggest contribution in forming silt (about 35\%) thinking at the geological structure. Associated with the bank erosion and the massive landslides in the omonime valley, in the bed of the river appears accumulation of blocks. The roads for forestry exploition have a contribution of 20-30\% ( Dumitriu, 2008) in forming badlands on important surfaces.

\section{General conclusions}

The main reasons which determined the floods in the last 10 years, with a maximum in 2005 and 2010, are: 
- Important precipitations ( over $130 \mathrm{l} / \mathrm{mp}$ ) beside the water from the land, in spring, which comers from the snow

- The damage of the embankments because of to much water and the long period (ove

- r 20 days when appeared infiltrations - fig. 7. a, b)

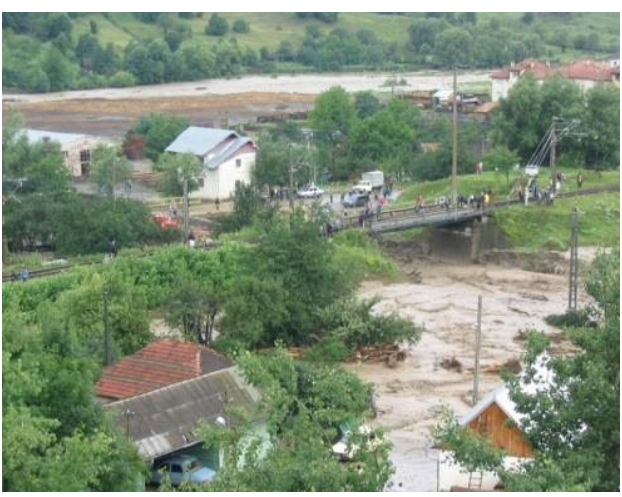

a)

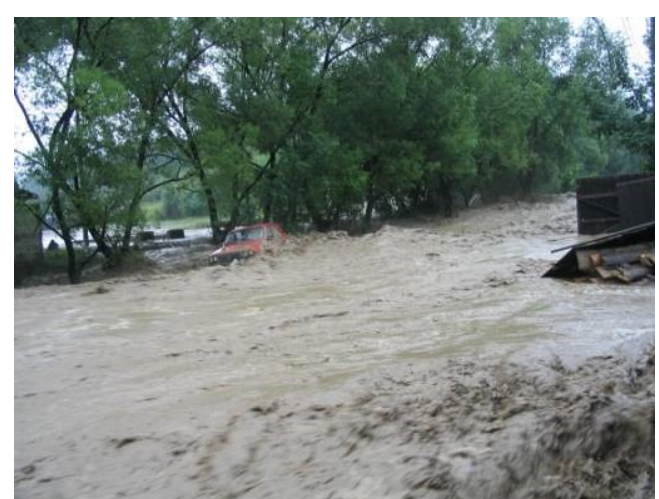

b)

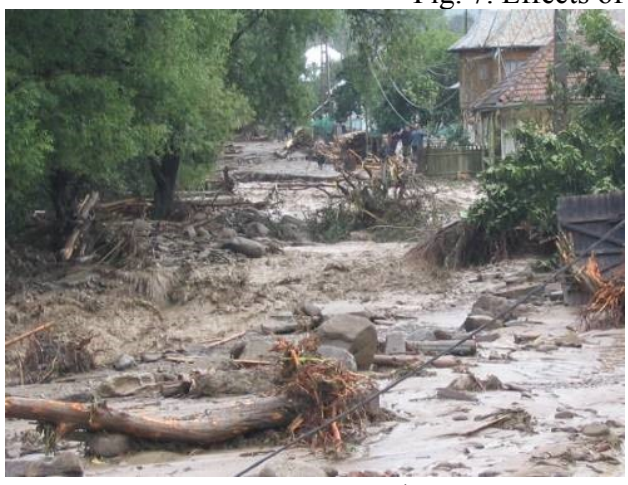

a)

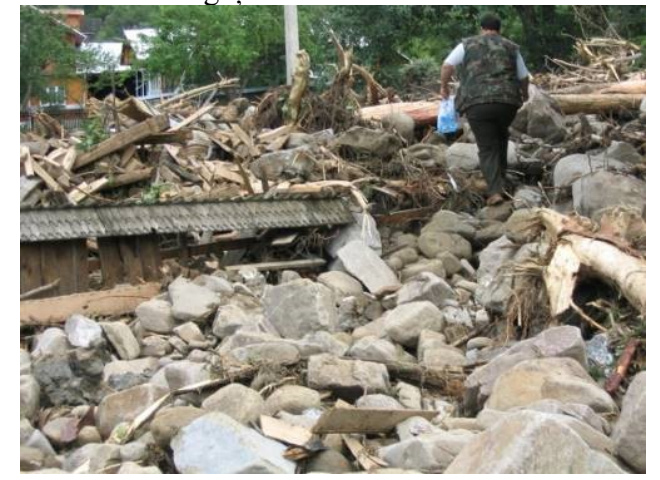

b)

Fig. 8. Effects of hazard event in Agăș

- massive deforestation and unsuited agrotechnical works which help the erosion and lead to a bigger flow and important quantities of silt (fig. 7. a, b)

- The gullies and ditches are not enough, and the ones that exist in the rural area are not well used and kept (fig. 7. b)

- The clogging and the bad keeping of the gullies and ditches, which are not enough and properly for floods (fig. 8. a, b)

- Unauthorized buildings that appear in the flood areas 
- Poverty, unauthorized buildings, bad projects, low quality materials and the lack of administrative rules for buildings (fig. 8. a, b)

- Overloaded transports on bridges and waste products which ruin the channels, already too few. Illegal deposits of sawdust from the major basins of Trotus and affluent are big pollutants

- The works around the bridges are not made according the legal notices

- The lack of enough materials and means of the local administration in case of floods

The ignorance of the people and the local administration how to interfere in case of climatic and hydrological hazards( to announce, to alarm the people).

\section{Acknowledgments}

Ovidiu-Miron Machidon is supported by a POSDRU grant no. 89/1.5/S/49944 "Developing the innovation capacity and improving the impact of research through postdoctoral programs", Alexandru Ioan Cuza University, Iasi.

\section{Refrences}

Apostol L. (2004) Clima Subcarpaților Moldovei. Editura Universităţii din Suceava

Dumitriu D. (2008) "Modele de evaluare a bugetului de aluviuni în relaţie cu impactul antropic dintr-un bazin hidrografic. Studiu de caz: bazinul râului Trotuş" - contract CNCSIS- UAIC Iaşi

Dumitriu D., Niculiță M., Condorache D. (2011) "Downstream Variation in the Pebble Morphometry of the Trotuş River, Eastern Carpathians (Romania)" in Forum geografic. Studii şi cercetări de geografie şi protecţia mediului - volume 10 (www.forumgeografic.ro)

Grozavu A., Kocsis L. (2006) "Effets géomorphologiques de la crue de 12/13 juillet 2005 $d u$ Bassin versant du ruisseau Albele (Département de Bacău)" în Analele ştiinţifice ale Universităţii "Al.I.Cuza" Iaşi. Tom LII, s.II-c, Geografie 2006: 60-66, Iaşi

Văcăraşu Iulia (1984) "Aşezările de altitudine din zona montană a Trotuşului şi rolul lor în modificarea peisajului geografic înconjurător" în Buletinul Societăţii de Ştiinţe Geografice din R.S.R., vol.VII: 88-93. Bucureşti.

$* * *$ Date pluviometrice masurate in intervalul $25-27.06 .2010$ de statiile hidrometrice din cadrul Directiei de Ape Siret - S.G.A. Bacau;

$* * *$ www.sat24.com/history.aspx

$* * * \mathrm{http}: / /$ weather.uwyo.edu/upperair/europe.html

$* * *$ www.wetter3.de/Archiv

$* * *$ www.wetter3.de 